University of New Hampshire

University of New Hampshire Scholars' Repository

$7-2010$

\title{
Geodatabase Development to Support Hyperspectral Imagery Exploitation
}

\author{
Robert A. Fusina \\ U.S. Naval Research Laboratory \\ John C. Fry \\ Marine Information Resources Corporation Email First Middle Last \\ C Reid Nichols \\ Marine Information Resources Corporation \\ Charles M. Bachmann \\ U.S. Naval Research Laboratory \\ Rong-Rong Li \\ U.S. Naval Research Laboratory
}

See next page for additional authors

Follow this and additional works at: https://scholars.unh.edu/ccom

Part of the Oceanography and Atmospheric Sciences and Meteorology Commons

\section{Recommended Citation \\ Fusina, Robert A.; Fry, John C.; Nichols, C Reid; Bachmann, Charles M.; Li, Rong-Rong; Sellars, Jon; Parrish, Christopher; Montes, Marcos J.; Gross, Carl; White, Stephen A.; Lee, Krista; and Jones, Christopher A., "Geodatabase Development to Support Hyperspectral Imagery Exploitation" (2010). IEEE International Geoscience and Remote Sensing Symposium (IGARSS). 785. \\ https://scholars.unh.edu/ccom/785}

This Conference Proceeding is brought to you for free and open access by the Center for Coastal and Ocean Mapping at University of New Hampshire Scholars' Repository. It has been accepted for inclusion in Center for Coastal and Ocean Mapping by an authorized administrator of University of New Hampshire Scholars' Repository. For more information, please contact Scholarly.Communication@unh.edu. 


\section{Authors}

Robert A. Fusina, John C. Fry, C Reid Nichols, Charles M. Bachmann, Rong-Rong Li, Jon Sellars,

Christopher Parrish, Marcos J. Montes, Carl Gross, Stephen A. White, Krista Lee, and Christopher A. Jones 


\title{
GEODATABASE DEVELOPMENT TO SUPPORT HYPERSPECTRAL IMAGERY EXPLOITATION
}

\author{
*Robert A. Fusina $\quad$ 'John C. Fry $\quad{ }^{\circ}$ C. Reid Nichols $\quad$ *Charles M. Bachmann $\quad *$ Rong-Rong Li \\ †Jon Sellars †Chris Parrish *Marcos J. Montes *Carl Gross \\ $\dagger$ Stephen A. White $¥$ Krista Lee $\neq$ Christopher A. Jones
}
*Naval Research Laboratory, Remote Sensing Division, Coastal Science and Interpretation Section, Code 7232, 4555 Overlook Ave., SW, Washington, D.C. 20375; bachmann@nrl.navy.mil
${ }^{\circ}$ Marine Information Resources Corporation, 12337 Pans Spring Court Ellicott City, Maryland 21042

\begin{abstract}
$†$ NOAA/NOS, National Geodetic Survey, Remote Sensing Division, 1315 East-West Hwy Silver Spring, MD 20910
\end{abstract}

†naval Post-Graduate School, Remote Sensing Center, Physics Department, 833 Dyer Road

Naval Postgraduate School, Monterey, CA 93943

\begin{abstract}
Geodatabase development for coastal studies conducted by the Naval Research Laboratory (NRL) is essential to support the exploitation of hyperspectral imagery (HSI). NRL has found that the remote sensing and mapping science community benefits from coastal classifications that group coastal types based on similar features. Selected features in project geodatabases relate to significant biological and physical forces that shape the coast. The project geodatabases help researchers understand factors that are necessary for imagery post processing, especially those features having a high degree of temporal and spatial variability. NRL project geodatabases include a hierarchy of environmental factors that extend from shallow water bottom types and beach composition to inland soil and vegetation characteristics. These geodatabases developed by NRL allow researchers to compare features among coast types. The project geodatabases may also be used to enhance littoral data archives that are sparse. This paper highlights geodatabase development for recent remote sensing experiments in barrier island, coral, and mangrove coast types.
\end{abstract}

Index Terms - geodatabase, coast type, hyperspectral imagery, ground control, geospatial analysis

\section{INTRODUCTION}

The NRL routinely investigates coastal regions, a dynamic environment that numerous researchers have tried to partition into descriptive groups [1], [2], [3]. This paper will summarize how data were archived during remote sensing campaigns conducted in littoral areas surrounding the Virginia Coast Reserve (VCR), Marine Corps Base Hawaii (MCB-HI), and Shoalwater Bay Training Area (SWBTA) in Queensland, Australia. The first investigation used NRL's Compact Airborne Spectral Imager (CASI) (www.itres.com), a visible and near infra-red (VNIR) hyperspectral sensor, to study the barrier island coast and lagoons found along Cape Charles, Virginia [4], [5], [6], [7]. The second study occurred during January and February 2009 and involved analysis of the coralline coast surrounding Kaneohe and Waimanalo Bays in Hawaii. A third experiment was conducted during May 2009 along the extensive mangrove coast surrounding Shoalwater Bay in Queensland, Australia. Remote sensing campaigns in Hawaii and Australia both used HyMap ${ }^{\mathrm{TM}}$, a VNIR 
and short-wave infra-red (SWIR) hperspectral sensor (www.hyvista.com), to acquire HSI over the study area.

All three investigations included a comprehensive calibration and validation component where scientists collected in-water optical data, meteorological data, geotechnical information and substrate reflectance data, and canopy and leaf level spectral reflectance. Calibration for bathymetry consisted of both in-water spectral reflectance profiles measured with an Analytical Spectral Devices (ASD) spectrometer as a function of depth for various bottom types with validation data provided by small boat soundings and beach surveys with post-processed kinematic GPS in the foreshore. Other beach properties measured along transects consisted of grain size profiles, substrate moisture, bearing strength, shear, as well as the in situ spectral reflectance and GPS location of each position along beach transects. Vegetation spectral libraries were also developed including both canopy and leaf level spectral reflectance to retrieve vegetation coverage maps.

\section{PROJECT GEODATABASES}

The geodatabase combines spatial data collected from the coast in a data repository that supports imagery analysis and remote sensing research. For the VCR, MCB-HI, and SWBTA remote sensing campaigns, NRL developed project geodatabases representing a barrier island, coral, and mangrove coast. The coastal geodatabases have a common look and feel and support the objective determination of the dominant influences contributing to the characteristics of a particular coast. They are also described in data reports produced following remote sensing campaigns [8], [9], and [10].

Once imagery post processing was complete, all HSI was stored in the geodatabase along with other forms of digital products (raster) such as nautical charts and historical images. Table 1 provides a list of data provided in the geodatabase.

Table 1. Selected geodatabase contents.

\begin{tabular}{|l|l|l|}
\hline Data Description & Type & Purpose \\
\hline Coastal Spectra & Text & Spectral Matching \\
\hline $\begin{array}{l}\text { Dynamic Deflection } \\
\text { Modulus }\end{array}$ & Text & Imagery Processing \\
\hline Geodetic Control & $\begin{array}{l}\text { Vecto } \\
\mathrm{r}\end{array}$ & Imagery Processing \\
\hline Imagery & Raster & Mapping \\
\hline
\end{tabular}

\begin{tabular}{|l|l|l|}
\hline $\begin{array}{l}\text { METOC Time Series } \\
\text { (e.g., winds, humidity, } \\
\text { visibility, water levels) }\end{array}$ & Text & $\begin{array}{l}\text { Atmospheric } \\
\text { Correction and } \\
\text { Imagery Processing }\end{array}$ \\
\hline Photographs & Raster & Imagery Processing \\
\hline Sediment Cores & Text & Imagery Processing \\
\hline Soundings & Text & Imagery Processing \\
\hline Underwater Spectra & Text & Spectral Matching \\
\hline
\end{tabular}

Data used for atmospheric correction, calibration, and validation of imagery (ascii text) forms the basis for a hierarchical coastal classification system. Data includes information ranging from grain size distributions (microscale) to prevailing winds (synoptic scale). Considerable background information (vector) provides the location of man-made objects, the extent of vegetation, and important ground control. Data extracted from the geodatabase supports the development of look up tables and models that are key to developing statistical relationships needed to produce bathymetric retrievals, bearing strength maps, and other coastal products.

NRL coastal remote sensing campaigns rely on a single-user geodatabase for individual GIS work in a desktop environment. The ArcGIS Desktop facilitates the analysis of observed data elements and parameters across investigations and coast types [11]. ESRI's ArcCatalog is used to store geographical information, while tabular data are stored as Microsoft ${ }^{\circledR}$ Excel spreadsheets divided into similar attribute data folders in Microsoft ${ }^{\circledR}$ Explorer. Study data are viewed using ArcMap. The geodatabase supports tasks such as atmospheric correction since information on atmospheric gases, winds, and waves are accessed to remove spectral atmospheric transmission and scattered path radiance from radiance data collected by hyperspectral imaging [12]. In addition, the geodatabase includes all ground-based or laboratorybased spectral libraries to identify key features in the imagery. In ArcMap and ArcGIS Explorer attribute data are accessed by linking to spreadsheets or document files. Linking to spreadsheets containing the attribute data allows one to view actual instrument measurements as well as graphs pertaining to the data. By utilizing the identify tool in ArcMap, links to attribute data spreadsheets, photographs, web sites, and text files can be accessed by simply clicking the hyperlink icon. ArcGIS Explorer also allows for access to important archives that are web-enabled such as weather station observations. One can link to website attribute data by clicking the shapefile and navigating to the website in the pop-up window. Project attribute 
data such as spreadsheets of bearing strength of beach sediments and the corresponding photographs are accessed through relative file pathname links in the contents section of the GIS.

For those researchers not having an ArcGIS Desktop license, NRL provides collaborators with a geodatabase that was built using ArcGIS Explorer 900, a free-ware version of ArcGIS Desktop. The freeware version has allowed non-ArcGIS specialists to be able to easily view quicklook format images of HSI; view and obtain data from GPS ground truth points; and use the attribute data for those points to develop mapping products with the use of HSI and ENVI. The combined data in the geodatabase was essential in the production of shallow water bathymetric charts, vegetation layers, and bearing strength maps. This work extends the work of Francis Shepard's classification system [1] to support the remote sensing and mapping science community.

\section{RESULTS}

The ArcGIS file geodatabase benefits NRL researchers for various structural, performance and data management reasons. It has few size limitations, allows the storage of vector, raster, and text products, is easily migrated to collaborators, and allows updates to spatial indexes. Geodatabase size is provided in Table 2 .

Table 2. NRL geodatabases contain considerable information that supports imagery analysis and map making.

\begin{tabular}{|l|l|l|l|l|}
\hline \multirow{2}{*}{$\begin{array}{l}\text { NRL Remote } \\
\text { Sensing Campaign }\end{array}$} & \multicolumn{3}{|c|}{ Size, GB } & $\begin{array}{l}\text { Total } \\
\text { Size }\end{array}$ \\
\cline { 2 - 5 } & Raster & Vector & Text & \\
\hline VCR & 704 & 2.2 & 0.8 & $707 \mathrm{~GB}$ \\
\hline MCB-HI & 222 & 0.8 & 0.2 & $223 \mathrm{~GB}$ \\
\hline SWBTA & 293 & 2.5 & 0.5 & $296 \mathrm{~GB}$ \\
\hline
\end{tabular}

The geodatabase contains rapidly accessible information. Ground control information (e.g., Ground and bathymetric surveys) supports geo-rectification and the tide synchronization of imagery collections. Meteorological data (e.g., wind speed, relative humidity, ozone, and aerosol data) supports atmospheric correction. Oceanographic information (e.g., water levels fluctuations and soundings) supports the retrieval of bathymetry from HSI. Geotechnical data, e.g., grain size distributions, are especially useful to support engineering studies. Figure 1 displays a typical geotechnical product describing the beach along a particular transect during the remote sensing campaign in Australia.

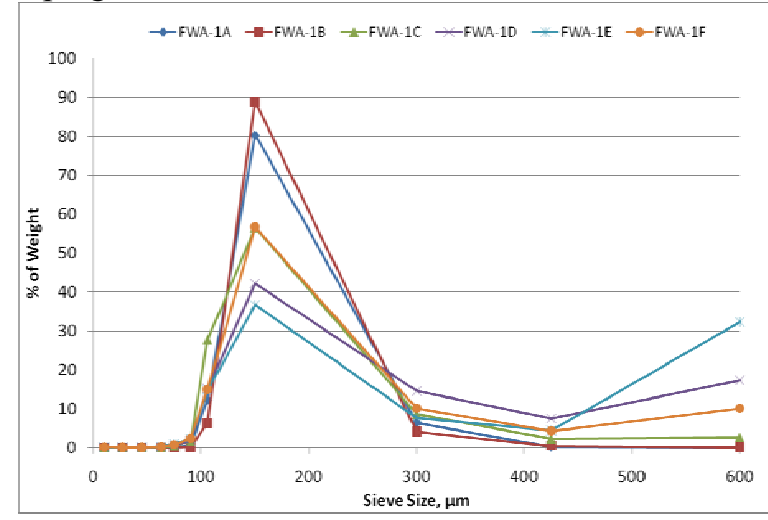

Figure 1. Comparison of grain size distributions along a transect at the SWBTA.

Grain size distribution data in addition to other forms of geotechnical data help to characterize coastal types and these data are used to develop bearing strength maps. Figure 2 presents a bearing strength map which was created from geotechnical data and HSI.

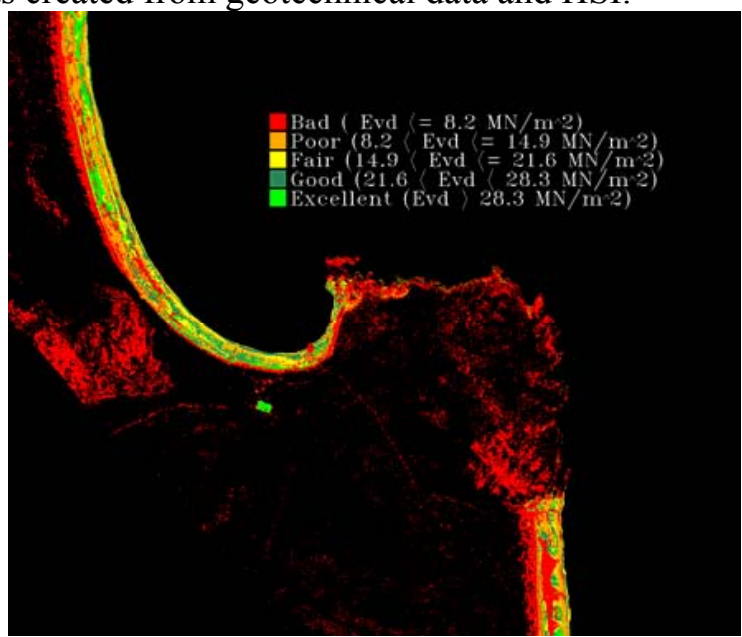

Figure 2. Bearing strength map created from geotechnical data collection at freshwater beach in the SWBTA.

The project geodatabases were provided to collaborators from University of Virginia for the VCR, resource managers from Marine Corps Installations for MCB-HI, and environmental managers from the Australian Defence Force and imagery analysts from the Naval Oceanographic Office for SWBTA.

\section{CONCLUSIONS}

The format of NRL project geodatabases are leading to a hierarchical coastal classifaction system. The project geodatabases help establish rules for key data layers and feature classes common to specific coast 
types. They are contributing to new algorithms and models which can be used to build HSI-based bearing strength map, shallow water bathymetric charts, and other coastal products for representative coast types.

\section{REFERENCES}

[1] Shepard, Francis P. 1973. Submarine Geology. New York:

Harper \& Row, 517 p.

[2] Inman, D. L., C. E. Nordstrom, 1971. Tectonic and

Morphologic Classification of Coasts, Journal of Geology, 79(1),

pp. 1-21.

[3] Wright, L.D., 1985, River deltas, in Davis, Jr., R. A., ed., Coastal sedimentary environments (2nd ed.): New York, NY, Springer Verlag, p. 1-76.

[4] Bachmann, C. M., M. J. Montes, R. A. Fusina, C. Parrish, J. Sellars, A. Weidemann, W. Goode, V. Hill, R. Zimmerman, C. R. Nichols, P. Woodward, K. McIlhany, D. Korwan, M. Crawford, J. Monty, B. Truitt, A. Schwarzschild, 2008b. "Very Shallow Water Bathymetry Retrieval from Hyperspectral Imagery at the Virginia Coast Reserve (VCR'07) Multi-Sensor Campaign," Proc.

IGARSS'08, Boston, MA, July 2008.

[5] Bachmann, C.M., M.J. Montes, R.A. Fusina, C. Parrish, J.

Sellars, A. Weidemann, W. Goode, C.R. Nichols, P.

Woodward, K. McIlhany, V. Hill, R. Zimmerman, D. Korwan, B.

Truitt, and A. Schwarzschild, Bathymetry Retrieval from

Hyperspectral Imagery in the Very Shallow Water Limit: A Case Study from the 2007 Virginia Coast Reserve (VCR'07) Multi-

Sensor Campaign, 2010, Marine Geodesy, Volume 33, Issue 1, pages $53-75$.

[6] Bachmann, C. M., C. R. Nichols, M. J. Montes, R.-R. Li, P. Woodward, R. A. Fusina, W. Chen, M. Crawford, V. Mishra, W.

Kim, J. Monty, K. McIlhany, K. Kessler, D. Korwan, D. Miller, E. Bennert, G. Smith, D. Gillis, J. Sellars, C. Parrish, A.

Schwarzschild, B. Truitt, 2008a. "Remote Sensing Retrieval of Substrate Bearing Strength from Hyperspectral Imagery at the Virginia Coast Reserve (VCR'07) Multi-Sensor Campaign," Proc. IGARSS'08, Boston, MA, July 2008.

[7]Bachmann, C. M., C. R. Nichols, M. Montes, R. Li, P. Woodward, R. A. Fusina, W. Chen, V. Mishra, W. Kim, J. Monty, K. McIlhany, K. Kessler, D. Korwan, D. Miller, E. Bennert, G. Smith, D. Gillis, J. Sellers, C. Parrish, A. Schwarzschild, B. Truitt, "Retrieval of Substrate Bearing Strength from Hyperspectral Imagery During the Virginia Coast Reserve (VCR '07) MultiSensor Campaign," Marine Geodesy, in press.

[8] VCR Data Report

[9] HI-HARES Data Report

[10] SWBTA Data Report

[11] Environmental Systems Research Institute, Geodatabase-Data Storage and Management for GIS. Available online. URL:

http://www.esri.com/software/arcgis/geodatabase/index.html. Accessed December 3, 2009.

[12] Montes, M.J., B.-C. Gao, and C. O. Davis, 2001, A new algorithm for atmospheric correction of hyperspectral remote sensing data, in Geo-Spatial Image and Data Exploitation II, William E. Roper, Editor, Proceedings of the SPIE, Vol. 4383, 2330 . 